\title{
A Novel Bacterial-Mediated Method for the Differentiation of Aedes spp. Larvae in Mixed-Nursery Assays and Its Application in the Determination of Vegetative Lysinibacillus sphaericus Biocontrol Efficiency in Invasive Vector Eradication
}

\author{
Mario Dániel-Gómez (D) and Jenny Dussán *(i) \\ Microbiological Research Center (CIMIC), Department of Biological Sciences, Universidad de Los Andes, \\ Bogotá 111711, Colombia; mf.daniel10@uniandes.edu.co \\ * Correspondence: jdussan@uniandes.edu.co; Tel.: +57-(1)339-4949
}

Citation: Dániel-Gómez, M.; Dussán, J. A Novel Bacterial-Mediated Method for the Differentiation of Aedes spp. Larvae in Mixed-Nursery Assays and Its Application in the Determination of Vegetative Lysinibacillus sphaericus Biocontrol Efficiency in Invasive Vector Eradication. Appl. Sci. 2021, 11, 3970. https://doi.org/10.3390/ app11093970

Academic Editor: Daniela Isola

Received: 26 February 2021

Accepted: 12 April 2021

Published: 27 April 2021

Publisher's Note: MDPI stays neutral with regard to jurisdictional claims in published maps and institutional affiliations.

Copyright: (c) 2021 by the authors Licensee MDPI, Basel, Switzerland. This article is an open access article distributed under the terms and conditions of the Creative Commons Attribution (CC BY) license (https:// creativecommons.org/licenses/by/ $4.0 /)$.
Featured Application: The developed coloration method employed the use of a genetically modified strain of the Escherichia coli bacterium, more specifically the pUC19 and red fluorescent protein (mRFP)-containing DH5 $\alpha$ strain. This bacterium was used in a coloration step previous to comparative mortality assays involving two Aedes species. This assessment allowed for the quick and easy differentiation between both Ae. albopictus and Ae. aegypti, and the results obtained shone light onto possible ecological variables to have in mind when applying biocontrollers in the wild. The evaluation of this method applied to differential mosquito lethality served as a proof of concept, and it is theorised that the same coloration method can be employed in similar comparative lethality studies relating to public health and beyond.

Abstract: The establishment of Aedes aegypti and the recent invasion of Aedes albopictus has put Colombia at risk, as it now harbours two arboviral vector species. Studies have shown the susceptibility of Aedes aegypti to the vegetative toxins produced by Lysinibacillus sphaericus. This study aims to determine the potential of two L. sphaericus strains in the control of both Aedes species present in Colombia, in both single and mixed species nurseries. Given the similarities between both species, there exists a need to differentiate them for the development of precise control strategies. Accordingly, mixed nurseries employed a red fluorescent protein (mRFP)-expressing Escherichia coli strain as a differentiator. Coloration-aided differentiation facilitated the analysis of mixed nursery treatments and provided deeper scrutiny into the variables at play. This showed an increase in the biocontrol efficiency, pointing to probable ecological variables. Bioassays involving Ae. albopictus showed a lower resistance to the one reported for Ae. aegypti in single-species nurseries. The study concludes that the use of E. coli strains expressing fluorescent proteins are useful tools to be employed in areas like public health entomology. Moreover, it was found that the use of L. sphaericus strains for biocontrol of vector mosquitoes is a viable alternative to chemical insecticides.

Keywords: E. coli; larvae differentiation; biological control; Lysinibacillus sphaericus; vegetative cell; Aedes spp.

\section{Introduction}

Dengue viruses (DENVs) are among the most common arboviral diseases currently affecting humankind, causing between 100 and 400 million infections every year [1]. These diseases have great public health relevance, as they are highly incapacitating, not only leading to economic damages but also generating serious health episodes and in some cases even death [2,3]. Despite interest and research, no specific antiviral treatments or vaccines exist. This means the main control strategy depends on Aedes (Stegomyia) vector mosquito management [4]. On account of its arboviral nature, the spread of Dengue 
viruses is limited to vector distributions, hence why mosquito density and dispersion are paramount criterions for the prediction and control of Dengue outbreaks [5]. In Colombia, the transmission of DENVs relies mainly on the vector Aedes aegypti (Linnaeus, 1762), but it has been shown that Aedes albopictus (Skuse, 1894) plays an important role as a secondary vector. This comes as no surprise, as Aedes mosquitoes have had a long coevolutionary history transmitting DENVs, which has made them into ideal vectors for these and other arboviral diseases [6]. However, this is not the only shared trait between these mosquito species, as they are practicably indistinguishable from one another during their larval stages, aside from minimal cuticle differences that do not manifest until the last larval instar [7]. The extent of these similarities is enough that there exists evidence of satyrization and even successful mating when their ranges overlap [8]. Ae albopictus is widely known as an important Dengue vector in Southeast Asia and Oceania [9], known also as the Tiger Mosquito, Ae. albopictus is native to Asia [10] but, in recent decades, it has been reported as an invasive species in different countries around the world [11,12]. The first American reports of the species date from 1986, when it was discovered in both Texas, USA and Sao Paulo, Brazil [13,14]. A little over a decade later, in 1998, the presence of Ae. albopictus in Colombia was first reported in the southern city of Leticia, in the Amazon region [15]. Widespread invasions of Ae. albopictus to different countries have been linked to the introduction of larvae and eggs carried accidentally through commerce, namely through imports like tires [11,16] and other suitable nesting materials [17]. Likewise, the main distribution path of the vector within Colombia is thought to be a consequence of terrestrial trade and movement of goods $[11,15,17]$. Currently, this vector is extensively distributed throughout the national territory $[18,19]$ and is thought to be resistant to many of the broad-spectrum insecticides used in its and Ae. aegypti's eradication [20]. Belonging to the Diptera order, these insects have a holometabolous development, meaning that their maturation process passes through the egg, larval instars, pupa, and adult stages [21]. It is well known that the larval stage of these insects is the easiest to control, does not present a danger of disease transmission and has shown greater susceptibility to various control methods [22]. Nevertheless, given the organisms' developmental speed, it is difficult to implement control projects within an adequate time frame.

The most broadly used vector control strategy has been the use of different pesticides in large quantities [23,24]. This method was successfully implemented during most of the 20 th century $[25,26]$. Yet, this strategy has been questioned for different reasons, mainly, bioaccumulation of toxins in biomass $[27,28]$, decomposition into even more environmentally toxic compounds $[29,30]$, action on non-target organisms [31,32], and the appearance of resistance in target organisms [20,24,33]. Therefore, both environmental organisations and the scientific community have condemned attempts to control vector mosquitoes through purely chemical means, as the detrimental health effects outweigh the relatively few benefits of the method.

In recent years, biotechnological exploits such as expression vectors have been thoroughly implemented and used across different fields in both industry and research applications, ranging from enabling protein expression in target organisms, to the creation of transgenic organisms $[34,35]$. Modified bacteria like some Escherichia coli strains possess plasmids containing fluorescent reporters like red fluorescent protein (mRFP) and are of great use as they can serve as easily distinguishable colorimetric bioindicators for environmental contaminants, which is the case of leftover antibiotics from both pharmaceutical and agricultural applications [36]. Despite the success expression vectors have had in other areas, they have not yet been employed in the control of arboviral diseases and, more specifically, in the differentiation of public health-relevant mosquito species, as is the case of Ae. albopictus and Ae. aegypti.

Lysinibacillus sphaericus is a Gram-positive, mesophilic, rod-shaped bacterium commonly found on soil [37]. It can form resistant endospores that are tolerant to high temperatures, chemicals, ultraviolet light, and can remain viable for long periods of time [37,38]. It has shown extensive potential as an insect pathogen and a biocontroller, mostly because 
of the Binary $(\operatorname{Bin} A / \operatorname{Bin} B)$ toxins [37], and previous studies have shown the specificity and little collateral damage caused by the implementation of L. sphaericus as a mosquito biocontroller on ecosystems and their dynamics [39]. Extensive research has been conducted on the entomopathogenic properties of the binary toxins present in the parasporal crystal [40-42], concluding that they are generally refractory to Aedes mosquitoes $[43,44]$. However, L. sphaericus has other mechanisms of toxicity against mosquitoes, namely the S-Layer protein [45-47] and the Mosquitocidal (Mtx 1/2/3) toxins present in the vegetative cell [48]. In the past, assessments with $M t x$ toxins, S-Layer preparations and vegetative L. sphaericus cells have been tested against Ae. aegypti larvae [40,42,47], but only one report exists on the S-Layer's entomopathogenic action against the novel invader species Ae. albopictus [45]. In this study, vegetative cells of L. sphaericus III(3)7, and 2362 (WHO reference) were assessed against Rockefeller reference Ae. aegypti and Colombian reference Ae. albopictus strains in order to assess the effectiveness of the bacterial biocontroller on the novel arboviral vector Ae. albopictus. In addition, the study aimed to determine the potential of two L. sphaericus strains in the control of the aforementioned Aedes species present in the country in both single and mixed species nurseries, employing an mRFP-expressing Escherichia coli strain as a differentiator between species.

\section{Materials and Methods}

The methodology employed and outlined below is a modification of the protocol utilised previously by Rojas-Pinzón and Dussán in 2017 [40].

\subsection{Lysinibacillus sphaericus, Aedes aegypti and Aedes albopictus Strains}

The L. sphaericus III(3)7 strain was isolated from an oak forest soil in Colombia [49]. The WHO reference strain 2362 was isolated from adult Simulium damnosum [50] and kindly donated by A. Delecluse from the Pasteur Institute in France. This bacterial mixture was selected as these strains have shown the most lethality in Ae. aegypti mosquitoes among the L. sphaericus strains present in the CIMIC collection, having a Lethal Dose 50 (LD50) concentration of $10^{7}$ colony-forming units per millilitre (CFU/mL) $[40,51,52]$. The eggs of the reference Ae. aegypti Rockefeller strain and the Colombian reference Ae. albopictus strain were kindly donated by the National Institute of Health (INS) in Bogotá, Colombia.

\subsection{Aedes Mosquito Maintenance}

Eggs donated by the INS were kept at $30^{\circ} \mathrm{C}$ and $60-70 \%$ relative humidity under a 12:12 light/dark photoperiod. Upon hatching, the larvae were fed with pellet food Omega One Natural Protein Formula (OmegaSea, LLC, Painesville, OH, USA) for cichlids, twice a week. The larvae were kept in plastic containers until the third development instar was reached. These conditions were used for both mosquito species.

\subsection{Bioassays of L. sphaericus against Individual Aedes Species Nurseries}

In order to determine precise LD50 concentrations for vegetative cells against each species, the two L. sphaericus strains were evaluated in several concentrations, which were derived from previous studies regarding Ae. aegypti lethality [40,51,52]. The selected concentrations ranged from $10^{4}$ to $10^{7} \mathrm{CFU} / \mathrm{mL}$. For the assays, the L. sphaericus strains were grown on nutrient agar (NA) at $30^{\circ} \mathrm{C}$. After $15 \mathrm{~h}$, cells were recovered in $1 \mathrm{~mL}$ of water, and serial dilutions were then made to calculate the bacterial titre that was added to the bioassays. In order to assess the mosquitocidal potential, the tests were conducted in $15 \mathrm{~mL}$ of chlorine-free water with 20 individuals and $15 \mathrm{~mL}$ of the bacterial suspension $\left(10^{4}\right.$ to $\left.10^{7} \mathrm{CFU} / \mathrm{mL}\right)$. All the trials were conducted in triplicate, and a control without bacteria was included. The number of live larvae were recorded every $24 \mathrm{~h}$ until $48 \mathrm{~h}$. This procedure was conducted for both mosquito species. Trials were performed keeping the maintenance parameters for temperature, photoperiod, and relative humidity. 


\subsection{Preparation, Toxicity Assessment and Coloration of Ae. aegypti Using mRFP-Modified E. coli}

Modified E. coli DH5 $\alpha$ cells containing the pUC19 plasmid with mRFP were activated in an overnight culture in Lysogeny Broth (LB) containing $50 \mu \mathrm{g} / \mathrm{mL}$ of Ampicillin at $30^{\circ} \mathrm{C}$ and $150 \mathrm{rpm}$. Serial dilutions were made, and the bacterial titre was estimated at $10^{8} \mathrm{CFU} / \mathrm{mL}$. A toxicity screen was performed by calculating the LC50. In order to do this, 10 Ae. aegypti larvae were subjected to tests in glass containers containing $15 \mathrm{~mL}$ of chlorinefree water and $15 \mathrm{~mL}$ of the $10^{8} \mathrm{CFU} / \mathrm{mL}$ bacterial suspension. This was conducted in duplicate and a control treatment containing $30 \mathrm{~mL}$ of chlorine-free water was included. Trials were conducted keeping the maintenance parameters for temperature, photoperiod, and relative humidity. Live larvae were counted every $24 \mathrm{~h}$ until $48 \mathrm{~h}$.

\subsection{Bioassays of L. sphaericus against Mixed Aedes Nurseries}

To evaluate natural competition nurseries, simulated nurseries containing individuals from both Aedes species were set up. The LC50 was determined employing the same procedure used in single-species nurseries, only modifying the number of individuals to 10 larvae per species per assay. Given the extent of the physical similarities between the two larvae species, especially during the first three instar stages, a novel differentiation method based on colour was developed. Through this method, larvae were differentiated employing the aforementioned modified E. coli strain, which expressed the fluorescent protein mRFP. Ingestion of this modified bacteria coloured the Ae. aegypti larvae pink/red. The colour treatment was carried out during the first 2 instars, before the larvae were placed into the mixed nursery environment. Further differences were employed to aid in the accurate differentiation, namely exoskeleton variations including the lateral comb and thorax hairs. Final bacterial concentrations employed in bioassays against each nursery type are specified in Table 1.

Table 1. Final bacterial concentration ( \pm Standard Deviation) in CFU $/ \mathrm{mL}$ of the Bacterial mixture (III(3)7 +2362$)$ tested against each Aedes species nursery type.

\begin{tabular}{ccccc}
\hline Nursery Type & $\mathbf{1 0}^{\mathbf{7}}$ & $\mathbf{1 0}^{\mathbf{6}}$ & $\mathbf{1 0}^{\mathbf{5}}$ & $\mathbf{1 0}^{\mathbf{4}}$ \\
\hline Ae. aegypti & $3.26 \times 10^{7}\left( \pm 5.89 \times 10^{5}\right)$ & $1.91 \times 10^{6}\left( \pm 8.28 \times 10^{4}\right)$ & $4.9 \times 10^{5}\left( \pm 1.5 \times 10^{4}\right)$ & $7.87 \times 10^{4}\left( \pm 3.17 \times 10^{2}\right)$ \\
\hline Ae. albopictus & $6.39 \times 10^{7}\left( \pm 7.32 \times 10^{4}\right)$ & $9.24 \times 10^{6}\left( \pm 2.71 \times 10^{4}\right)$ & $3.76 \times 10^{5}\left( \pm 6.86 \times 10^{4}\right)$ & $3.22 \times 10^{4}\left( \pm 9.27 \times 10^{3}\right)$ \\
\hline Mixed & $3.54 \times 10^{7}\left( \pm 9.51 \times 10^{5}\right)$ & $6.12 \times 10^{6}\left( \pm 6.42 \times 10^{5}\right)$ & $9.69 \times 10^{5}\left( \pm 2.91 \times 10^{4}\right)$ & $4.57 \times 10^{4}\left( \pm 5.93 \times 10^{3}\right)$ \\
\hline
\end{tabular}

\subsection{Statistical Analysis}

In order to construct the corresponding mortality curves and determine the lethal doses for the different treatments, the Probit model was implemented [53]. The Probit model was constructed in Microsoft Excel [54]. The mortality values were then subjected to further statistical analysis. All statistical tests were performed using the R 3.1.2 statistical package [55], and a significance level of $p<0.05$ was chosen for every test. Homoscedasticity was evaluated and confirmed through Bartlett's test for homogeneity of variance, and data normality was assessed and verified through a Shapiro-Wilk normality test (Table S1). In order to assess statistically significant differences between mortality per treatment in the $A e$. albopictus strain, analysis of variance (ANOVA) (one way) tests were performed followed by Tukey's Honestly Significant Difference (HSD) tests as a post hoc analysis (Table S2).

\section{Results}

\subsection{Toxicity Assessment and Coloration of Ae. aegypti Using mRFP-Modified E. coli}

The LB culture media turned bright pink past $20 \mathrm{~h}$ of incubation (Figure 1A), thus confirming both the presence and activation of the mRFP reporter in the cultured bacteria. Once mRFP activation was confirmed, Ae. aegypti larvae were exposed to the bacteria to evaluate colouration and possible antagonism. Past $24 \mathrm{~h}$, no larval mortality was registered, and evidence of ingestion could be seen within the larvae's digestive tract, as it was coloured pink (Figure 1B). 


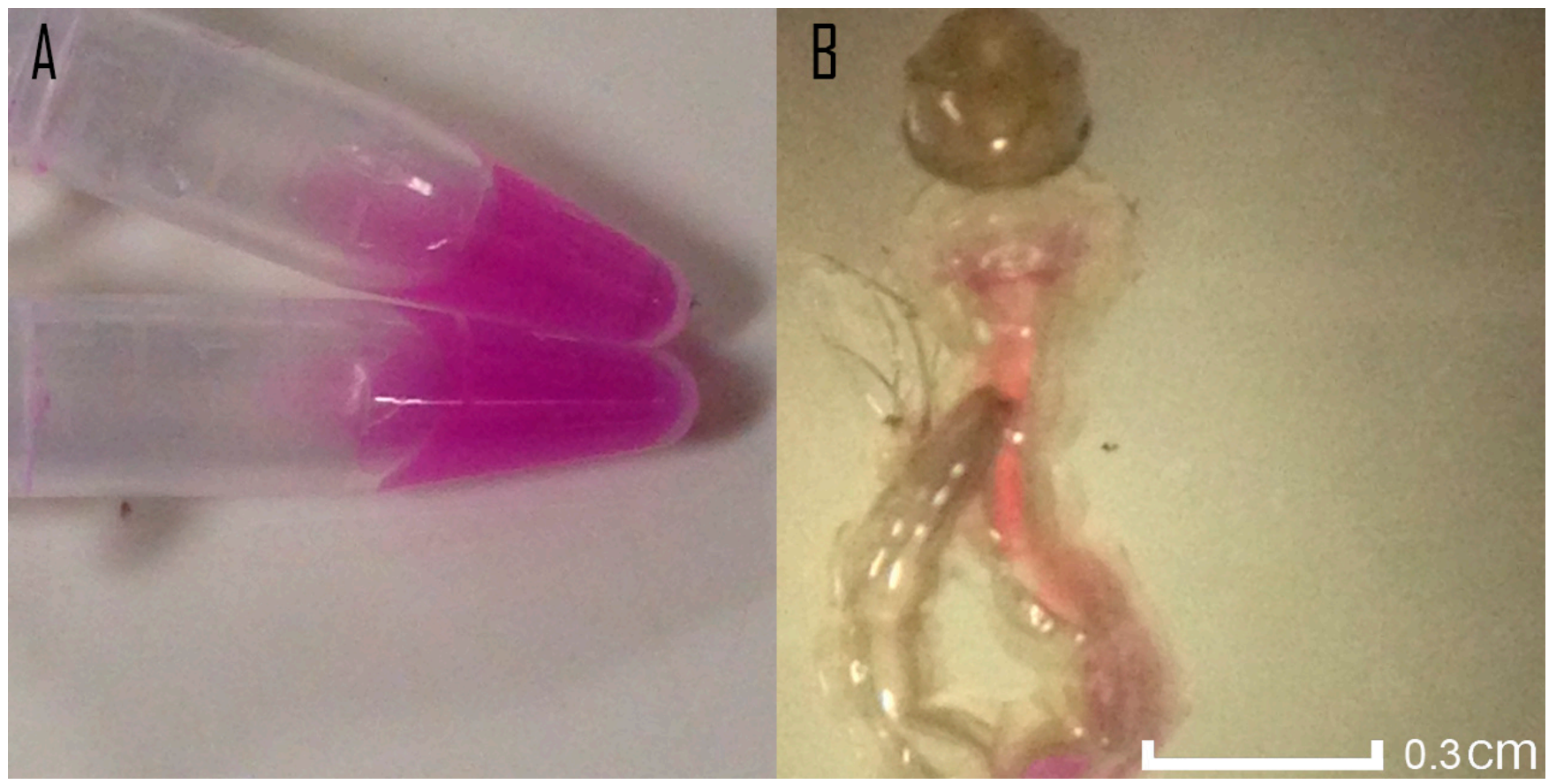

Figure 1. (A) Modified E. coli expressing the red fluorescent protein (mRFP) after being exposed to antibiotic. (B) Colouration observed within the larvae's digestive tract after the ingestion of modified E. coli expressing mRFP.

\subsection{Lethal Doses for and among Different Aedes Nurseries}

For the Ae. albopictus nurseries, LD50 for the mixture of L. sphaericus 2362 and III(3)7 was found to be $5.9 \times 10^{5} \mathrm{CFU} / \mathrm{mL}\left(\mathrm{R}^{2}=0.95, \mathrm{y}=14.829 \times-26.566\right)$. Ae. aegypti nurseries showed a comparative resistance, having a LD50 value of $1.8 \times 10^{7} \mathrm{CFU} / \mathrm{mL}\left(\mathrm{R}^{2}=0.82\right.$, $y=16.455 \times-28.676)$. Mixed species nurseries showed a slight decrease in resistance, presenting a LD50 value of $1.45 \times 10^{7}\left(\mathrm{R}^{2}=0.87, \mathrm{y}=15.96 \times-27.23\right)$, marginally lower than the one found in Ae. aegypti nurseries. All values are reported in Table 2.

Table 2. Lethal Lysinibacillus sphaericus bacterial mixture (III(3)7 + 2362) doses for each of the treatment nurseries.

\begin{tabular}{ccc}
\hline Nursery Type & LD50 (CFU/mL) & LD95 (CFU/mL) \\
\hline Ae. aegypti & $1.8 \times 10^{7}$ & $6.3 \times 10^{7}$ \\
\hline Ae. albopictus & $5.9 \times 10^{5}$ & $1.23 \times 10^{6}$ \\
\hline Mixed (both species) & $1.45 \times 10^{7}$ & $3.04 \times 10^{7}$ \\
\hline Mixed (Ae. aegypti) & $7.23 \times 10^{6}$ & $3.25 \times 10^{7}$ \\
\hline Mixed (Ae. albopictus) & $1.88 \times 10^{5}$ & $9.74 \times 10^{5}$ \\
\hline
\end{tabular}

\subsection{Bioassays against Different Bacterial Inoculum Concentrations}

Correlating to the lethal doses found, a dose-dependent effect was observed between Aedes larvae mortality and bacterial inoculum dose. Results found fall in line with previous investigations, as Ae. aegypti was able to tolerate inoculums as high as $10^{7} \mathrm{CFU} / \mathrm{mL}$ [51]. A dose-dependent effect was evident among all nursery types (Figure 2), with Ae. albopictus showing greater susceptibility to the bacterial treatment, particularly in the $10^{5}-10^{6} \mathrm{CFU} / \mathrm{mL}$ range. Significant differences were found among the inoculated treatments and the controls for all nursery types except $10^{4} \mathrm{CFU} / \mathrm{mL}$ at both $24 \mathrm{~h}(\mathrm{Ae}$. albopictus: ANOVA: $\mathrm{F}(4,10)=548, p<0.0001$. Average larval mortality per inoculum dose: 104: 0\%, 105: 55\%, 106: 96\%, 107: 100\%; Ae. aegypti: ANOVA: $\mathrm{F}(4,10)=23.54, p<0.0001$. Average larval mortality per inoculum dose: $10^{4}: 0 \%, 10^{5}: 15 \%, 10^{6}: 30 \%, 10^{7}: 95 \%$; mixed nurseries: ANOVA: $\mathrm{F}(4,10)=104, p<0.0001$. Average larval mortality per inoculum dose: 
$\left.10^{4}: 0 \%, 10^{5}: 35 \%, 10^{6}: 55 \%, 10^{7}: 100 \%\right)$ and $48 \mathrm{~h}$ (Ae. albopictus: ANOVA: $\mathrm{F}(4,10)=337.9$, $p<0.0001$. Average larval mortality per inoculum dose: $10^{4}: 10 \%, 10^{5}: 82 \%, 10^{6}: 100 \%, 10^{7}$ : 100\%; Ae. aegypti: ANOVA: $\mathrm{F}(4,10)=87.6, p<0.0001$. Average larval mortality per inoculum dose: $10^{4}: 7 \%, 10^{5}: 18 \%, 10^{6}: 45 \%, 10^{7}: 100 \%$; Mixed nurseries: ANOVA: $\mathrm{F}(4,10)=257.9$, $p<0.0001$. Average larval mortality per inoculum dose: $10^{4}: 8 \%, 10^{5}: 50 \%, 10^{6}: 70 \%$, $10^{7}: 100 \%$ ) past inoculation. Results indicate the presence of a clear dose-dependent relationship. This relationship is further solidified by the results from the overall mortality across all inoculum concentrations (Figure 3), which again showed statistical significance when compared to the control treatments at both $24 \mathrm{~h}$ (ANOVA: $\mathrm{F}(4,40)=45.54, p<0.0001$. Average larval mortality per inoculum dose: $10^{4}: 0 \%, 10^{5}: 35 \%, 10^{6}: 55 \%, 10^{7}: 100 \%$ ) and $48 \mathrm{~h}$ (ANOVA: $\mathrm{F}(4,40)=50.07, p<0.0001$. Average larval mortality per inoculum dose: $10^{4}$ : $\left.8 \%, 10^{5}: 50 \%, 10^{6}: 70 \%, 10^{7}: 100 \%\right)$.
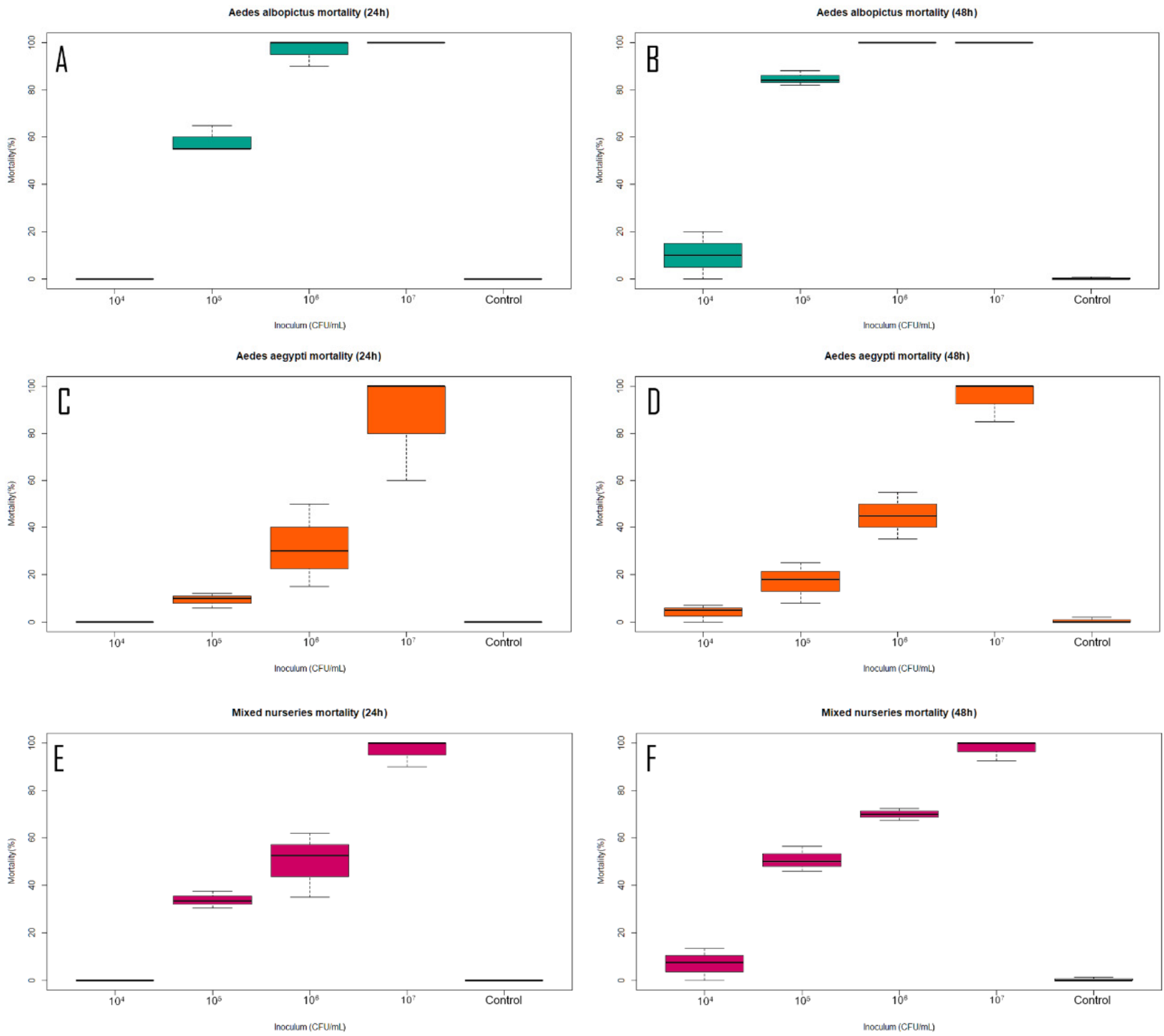

Figure 2. Dose-dependent responses of the different Aedes nurseries when exposed to the different inoculum concentrations used at the set time intervals. (A) Aedes albopictus nurseries (24 h post inoculation). (B) Aedes albopictus nurseries (48 $\mathrm{h}$ post inoculation). (C) Aedes aegypti nurseries (24 h post inoculation). (D) Aedes aegypti nurseries (48 $\mathrm{h}$ post inoculation). (E) Mixed nurseries (24 h post inoculation). (F) Mixed nurseries ( $48 \mathrm{~h}$ post inoculation). 

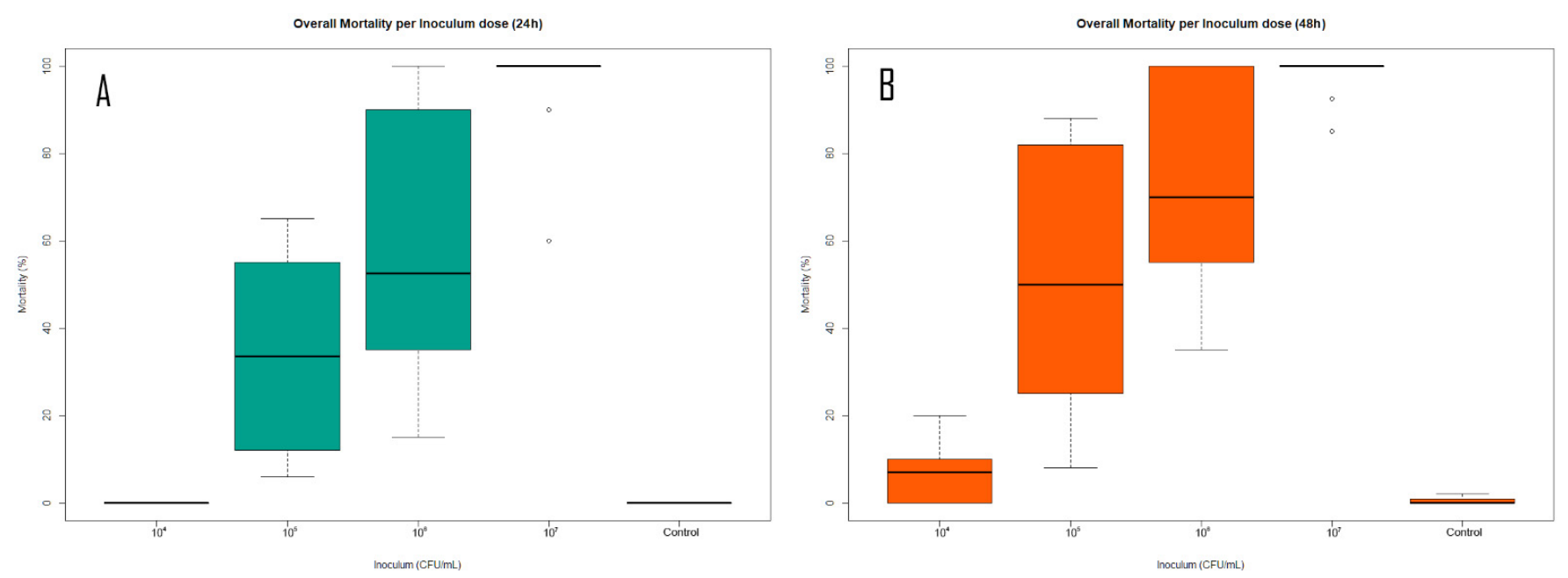

Figure 3. Overall dose-dependent response observed for the different inoculum concentrations used. (A) $24 \mathrm{~h}$ past initial exposure. (B) $48 \mathrm{~h}$ past initial exposure.

\subsection{Nursery Response to Biocontrol Agent}

All three nursery types responded similarly to the biocontrol agent and, as stated above, some instances of resistance and sensitivity were recorded. Nevertheless, these results were not apparent whilst comparing overall mortality between nursery types at the set time intervals (Figure 4). Additionally, no significant difference was found between the species after performing the statistical analysis at neither $24 \mathrm{~h}$ ANOVA: $\mathrm{F}(2,42)=1.541$, $p=0.2261$ ) nor $48 \mathrm{~h}$ (ANOVA: $\mathrm{F}(4,40)=1.611, p=0.2117$ ). This indicates a similar biocontrol behaviour among all nursery types, pointing to L. sphaericus as an adequate biocontrol solution regardless of nursery type.
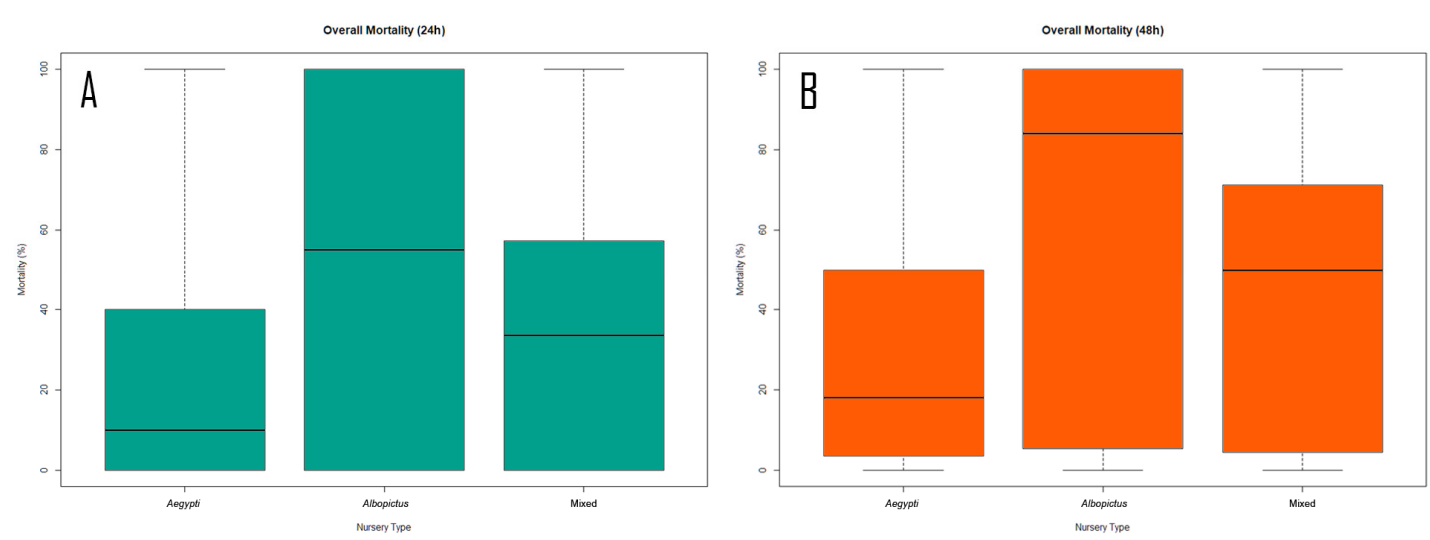

Figure 4. (A) Overall mortality among all the nursery types tested over all the inoculum concentrations used after (A) $24 \mathrm{~h}$ past initial exposure. (B) $48 \mathrm{~h}$ past initial exposure.

\section{Discussion}

4.1. Toxicity Assessment and Coloration of Ae. aegypti Using mRFP-Modified E. coli

The lack of larval mortality indicated that the colouration treatment would not cause noise during the LD50 calculations involving the biocontroller. In addition, the successful colouring of Ae. aegypti larvae greenlit the mixed nurseries treatment, as there was a viable and fast way of differentiating both larval species. The results obtained are congruent with current literature, as it has been reported that not only are gut bacteria innocuous to mosquitoes [56], but they also contribute to their development through a hypoxia-induced growth mechanism [57]. That being said, no size or instar difference was observed between bacteria grown with and without the bacterial colouring agent in this study. 


\subsection{Lethal Doses for and among Different Aedes Nurseries}

While corroborating the previously reported lethality values found for L. sphaericus interacting with Ae. aegypti [40], Probit analysis showed differences between the LD50 and LD95 among both species, pointing at an apparent acute sensibility in Ae. albopictus. These results contrast sharply with the current literature, as it has been previously reported that Ae. albopictus has a greater expansion potential [58] as well as an important plasticity and adaptative potential $[59,60]$ across different invaded landscapes. The results found seem to support the hypothesis where bacterial communities present at the breeding site have an important influence over intra and interspecific competition outcome, especially affecting Ae. albopictus $[61,62]$. This apparent susceptibility to native bacterial diversity could be an important factor explaining why the invasion of this vector has had a relatively slow spread throughout the Colombian territory $[63,64]$. The treatment involving mixed nurseries pointed towards Ae. aegypti being more resistant to the biocontroller in mixed nurseries, and a slight decrease in resistance was observed, though no significant differences were found in larvae mortality while comparing both species with the single species nurseries treatments. Furthermore, mixed nurseries showed a slight drop in lethal doses, particularly in the LD95 value, pointing at plausible negative ecological interactions between the target species [65] (Table 2). The colorimetric treatment involving the modified mRFP-expressing E. coli was a key factor in the visualisation and the detailed determination of larval mortality in the mixed nursery environment, as it helped minimise errors in larval count, providing accurate measures for lethality. This is of special importance while working in enclosed environments, such as the one used in this study, as both inter, and intraspecific competition play key roles in larval development times and survival [66]; however, it has been recently suggested that intraspecific competition may be less detrimental to larvae survival and development than intraspecific competition [67]. The decrease in the LD95 shown between pure Ae. aegypti and mixed nurseries points at intraspecific competition as a detrimental factor in a pathogen-laced environment, which considerably reduced the survival of the fittest species. Given how wild mixed nurseries are not as rare as previously thought [68], the use of a bacterial biocontroller such as L. sphaericus can benefit from the natural competition between the two vector species, further enhancing its efficiency in the field.

\subsection{Bioassays against Different Bacterial Inoculum Concentrations}

A clear dose-dependent effect was seen between the bacterial inoculum and the mosquito mortality, regardless of nursery type. The previously reported results for Ae. aegypti tolerance were congruent with doses found during the study [40,52]. On the other hand, this study represents the first time Ae. albopictus' tolerance to the biocontroller L. sphaericus has been tested. In the past, it has only been exposed to the bacterium's S-Layer protein [45], which alone had notable impact on the insect's mortality. Mixed nurseries showed an increase in Ae. aegypti susceptibility to the bacterial treatment when compared to pure nurseries, this can correlate to negative ecological interactions between and within the target species, namely intra and interspecific competition for space and nourishment $[66,67]$.

\subsection{Nursery Response to Biocontrol Agent}

The overall results show no specificity towards a particular Aedes nursery, as well as an ample biocontrol potential at the employed inoculum concentrations. With this in mind, the potential use of $L$. sphaericus as a vector control alternative cannot be overlooked, as no specific strategies are being used against Ae. albopictus in Colombia [20,33]. Coupled with this, the worrying appearance of resistance $[20,24]$ to chemical control methods, as well as the inherent disadvantages of present chemical control [27-29,31,32] has created an urgent need for the application of novel vector eradication strategies, and since larval stages are especially easy to control [22], the time is ripe for the usage of target-specific and environmentally friendly $[39,48]$ control methods such as the use of L. sphaericus as a larvae 
biocontroller and Wolbachia pipientis as an adult lifespan shortener [69] in the battle against Dengue and every other arboviral disease currently affecting the Colombian population.

\section{Conclusions}

In summary, the reference Ae. albopictus strain was susceptible to the vegetative cells of the L. sphaericus strains employed, which further establishes the mosquitocidal activity of this bacterium. The mRFP marking protocol permitted an in-depth evaluation of larval mortality in a mixed nursery environment and permitted the speculation on the different ecological variables at play in such a setting. Delving into the details of mosquito interactions with both the biocontroller and the competing species is paramount for the correct application of control strategies, and such a comparison would have been cumbersome at best without the use of a differentiation method like the one employed. For a better understanding of the vegetative cells' effect on Ae. albopictus larvae, future studies involving both field-collected and reference strains should be conducted. Additionally, in order to find out the role of chitinases, hemolysins and other toxic proteins genes annotated in several L. sphaericus genomes, further studies are needed. Given that the bacterial mixture was marginally more efficient causing larvae mortality in Ae. albopictus rather than Ae. aegypti, different formulations should be assessed. The results indicate that the vegetative cells of $L$. sphaericus are a suitable alternative, which can be used to deal with novel secondary vector populations such as that of Ae. albopictus in Colombia.

Supplementary Materials: The following are available online at https://www.mdpi.com/article/10 .3390/app11093970/s1, Table S1: Statistical analyses of homoscedasticity and normality, Table S2: Post hoc analyses of significance between treatments.

Author Contributions: Conceptualisation, M.D.-G., J.D.; methodology, M.D.-G., J.D.; validation, M.D.-G., J.D.; formal analysis, M.D.-G.; investigation, M.D.-G., J.D.; resources, M.D.-G., J.D.; data curation, M.D.-G. Writing_-original draft preparation, M.D.-G.; writing—review and editing, M.D.-G., J.D.; visualisation, M.D.-G., J.D.; supervision, J.D.; project administration, J.D.; funding acquisition, J.D. All authors have read and agreed to the published version of the manuscript.

Funding: This study was funded by the Research Fund INV-2019-84-1827 at the Science Faculty at Universidad de los Andes and the Microbiological Research Center (CIMIC).

Institutional Review Board Statement: Not applicable.

Informed Consent Statement: Not applicable.

Data Availability Statement: The data presented in this study are available on request from the corresponding author.

Acknowledgments: We are grateful to the National Institute of Health (INS) in Bogotá, Colombia, for the donated individuals. We are also grateful to the other members of the Microbiological Research Centre (CIMIC) for their support throughout the realisation of this investigation, as well as Maria Cristina Carrasquilla Ferro and Camila Gonzales Rosas of the Microbiology and Tropical Parasitology Research Center (CIMPAT) for their assistance during the mosquito differentiation process. We are also grateful to Paula Andrea Rojas Pinzón for taking and providing pictures of coloured larvae and Lysinibacillus sphaericus bacteria, and to Scarlett Olivo for the assistance during the creation of the graphical abstract.

Conflicts of Interest: The authors declare no conflict of interest.

\section{References}

1. Bhatt, S.; Gething, P.W.; Brady, O.J.; Messina, J.P.; Farlow, A.W.; Moyes, C.L.; Drake, J.M.; Brownstein, J.S.; Hoen, A.G.; Sankoh, O.; et al. The Global Distribution and Burden of Dengue. Nature 2013, 496, 504-507. [CrossRef] [PubMed]

2. Laserna, A.; Barahona-Correa, J.; Baquero, L.; Castañeda-Cardona, C.; Rosselli, D. Economic Impact of Dengue Fever in Latin America and the Caribbean: A Systematic Review. Rev. Panam. Salud Publica 2018, 42, e111. [CrossRef] [PubMed]

3. Guzman, M.G.; Harris, E. Dengue. Lancet 2015, 385, 453-465. [CrossRef]

4. Heintze, C.; Garrido, M.V.; Kroeger, A. What Do Community-Based Dengue Control Programmes Achieve? A Systematic Review of Published Evaluations. Trans. R. Soc. Trop. Med. Hyg. 2007, 101, 317-325. [CrossRef] 
5. Bäck, A.T.; Lundkvist, A. Dengue Viruses-An Overview. Infect. Ecol. Epidemiol. 2013, 3, 19839.

6. Powell, J.R. Mosquito-Borne Human Viral Diseases: Why Aedes aegypti? Am. J. Trop. Med. Hyg. 2018, 98, 1563-1565. [CrossRef]

7. Farajollahi, A.; Price, D.C. A Rapid Identification Guide for Larvae of the Most Common North American Container-Inhabiting Aedes Species of Medical Importance. J. Am. Mosq. Control Assoc. 2013, 29, 203-221. [CrossRef]

8. Bargielowski, I.E.; Lounibos, L.P.; Shin, D.; Smartt, C.T.; Carrasquilla, M.C.; Henry, A.; Navarro, J.C.; Paupy, C.; Dennett, J.A. Widespread Evidence for Interspecific Mating between Aedes aegypti and Aedes albopictus (Diptera: Culicidae) in Nature. Infect. Genet. Evol. 2015, 36, 456-461. [CrossRef]

9. Reiter, P.; Fontenille, D.; Paupy, C. Aedes albopictus as an Epidemic Vector of Chikungunya Virus: Another Emerging Problem? Lancet Infect. Dis. 2006, 6, 463-464. [CrossRef]

10. Smith, C.G. The history of dengue in tropical Asia and its probable relationship to the mosquito Aedes aegypti. J. Trop. Med. Hyg. 1956, 59, 243-251.

11. Reiter, P.A. Aedes albopictus and the world trade in used tires, 1988-1995: The shape of things to come? J. Am. Mosq. Control Assoc. 1998, 14, 83-94. [PubMed]

12. Gratz, N.G. Critical Review of the Vector Status of Aedes albopictus. Med. Vet. Entomol. 2004, 18, 215-227. [CrossRef]

13. Centers for Disease Control (CDC). Aedes albopictus introduction-Texas. MMWR. Morb. Mortal. Wkly. Rep. 1986, 35, 141-142.

14. De Brito, M.; Marques, G.R.A.M.; Marques, C.C.A.; Tubaki, R.M. Primeiro Encontro de Aedes (Stegomyia) albopictus (Skuse) No Estado de São Paulo (Brasil). Rev. Saude Publica 1986, 20, 489. [CrossRef]

15. Vélez, I.D.; Quiñones, M.L.; Suárez, M.; Olano, V.; Murcia, L.M.; Correa, E.; Arévalo, C.; Pérez, L.; Brochero, H.; Morales, A. Presencia de Aedes albopictus En Leticia, Amazonas, Colombia. Biomedica 1998, 18, 192. [CrossRef]

16. Hawley, W.A.; Reiter, P.; Copeland, R.S.; Pumpuni, C.B.; Craig, G.B., Jr. Aedes albopictus in North America: Probable Introduction in Used Tires from Northern Asia. Science 1987, 236, 1114-1116. [CrossRef]

17. Hawley, W.A. The biology of Aedes albopictus. J. Am. Mosq. Control Assoc. Suppl. 1988, 1, 1-39.

18. Rúa-Uribe, G.; Suárez-Acosta, C.; Londoño, V.; Sánchez, J.; Rojo, R.; Bello-Novoa, B. Detección de Aedes albopictus (Skuse) (Diptera: Culicidae) en la ciudad de Medellín, Colombia. Biomédica 2011, 31, 243-244.

19. Cuéllar-Jiménez, M.E.; Velásquez-Escobar, O.L.; González-Obando, R.; Morales-Reichmann, C.A. Detection of Aedes albopictus (Skuse) (Diptera: Culicidae) in the city of Cali, Valle del Cauca, Colombia. Biomédica 2007, 27, 273-279. [CrossRef]

20. Grisales, N.; Poupardin, R.; Gomez, S.; Fonseca-Gonzalez, I.; Ranson, H.; Lenhart, A. Temephos Resistance in Aedes aegypti in Colombia Compromises Dengue Vector Control. PLoS Negl. Trop. Dis. 2013, 7, e2438. [CrossRef]

21. Ramasamy, R.; Surendran, S.N.; Jude, P.J.; Dharshini, S.; Vinobaba, M. Larval Development of Aedes aegypti and Aedes albopictus in Peri-Urban Brackish Water and Its Implications for Transmission of Arboviral Diseases. PLoS Negl. Trop. Dis. 2011, 5, e1369. [CrossRef] [PubMed]

22. Benelli, G. Research in Mosquito Control: Current Challenges for a Brighter Future. Parasitol. Res. 2015, 114, 2801-2805. [CrossRef] [PubMed]

23. Metcalf, R.L. Century of DDT. J. Agric. Food Chem. 1973, 21, 511-519. [CrossRef] [PubMed]

24. Wanjala, C.L.; Mbugi, J.P.; Ototo, E.; Gesuge, M.; Afrane, Y.A.; Atieli, H.E.; Zhou, G.; Githeko, A.K.; Yan, G. Pyrethroid and DDT Resistance and Organophosphate Susceptibility among Anopheles spp. Mosquitoes, Western Kenya. Emerg. Infect. Dis. 2015, 21, 2178-2181. [CrossRef]

25. Harrison, G. Mosquitoes, Malaria and Man: A History of the Hostilities Since 1880; Dutton: Boston, MA, USA, 1978.

26. Garrett, L. The Coming Plague: Newly Emerging Diseases in a World out of Balance; Farrar, Straus and Giroux: New York, NY, USA, 1994.

27. Geisz, H.N.; Dickhut, R.M.; Cochran, M.A.; Fraser, W.R.; Ducklow, H.W. Melting Glaciers: A Probable Source of DDT to the Antarctic Marine Ecosystem. Environ. Sci. Technol. 2008, 42, 3958-3962. [CrossRef]

28. Greenberg, D.S. Pesticides: White House Advisory Body Issues Report Recommending Steps to Reduce Hazard to Public. Science 1963, 140, 878-879. [CrossRef] [PubMed]

29. El-Temsah, Y.S.; Sevcu, A.; Bobcikova, K.; Cernik, M.; Joner, E.J. DDT Degradation Efficiency and Ecotoxicological Effects of Two Types of Nano-Sized Zero-Valent Iron (NZVI) in Water and Soil. Chemosphere 2016, 144, 2221-2228. [CrossRef]

30. Kim, J.; Sun, Q.; Yue, Y.; Yoon, K.S.; Whang, K.-Y.; Clark, J.M.; Park, Y. 4,4'-Dichlorodiphenyltrichloroethane (DDT) and 4,4'Dichlorodiphenyldichloroethylene (DDE) Promote Adipogenesis in 3T3-L1 Adipocyte Cell Culture. Pestic. Biochem. Physiol. 2016, 131, 40-45. [CrossRef]

31. Eskenazi, B.; Chevrier, J.; Rosas, L.G.; Anderson, H.A.; Bornman, M.S.; Bouwman, H.; Chen, A.; Cohn, B.A.; de Jager, C.; Henshel, D.S.; et al. The Pine River Statement: Human Health Consequences of DDT Use. Environ. Health Perspect. 2009, 117, $1359-1367$. [CrossRef]

32. Connell, D.W.; Lam, P.; Richardson, B.; Wu, R. Introduction to Ecotoxicology, 1st ed.; Blackwell Science: Philadelphia, PA, USA, 2009.

33. Sharma, V.P. Current scenario of malaria in India. Parassitologia 1999, 41, 349-353.

34. Wacker, M.; Linton, D.; Hitchen, P.G.; Nita-Lazar, M.; Haslam, S.M.; North, S.J.; Aebi, M. N-linked glycosylation in Campylobacter jejuni and its functional transfer into E. coli. Science 2002, 298, 1790-1793. [CrossRef]

35. Gong, Z.; Wan, H.; Tay, T.L.; Wang, H.; Chen, M.; Yan, T. Development of Transgenic Fish for Ornamental and Bioreactor by Strong Expression of Fluorescent Proteins in the Skeletal Muscle. Biochem. Biophys. Res. Commun. 2003, 308, 58-63. [CrossRef] 
36. Molina, T.L.; Patel, R.; Molina, D.D.; Persans, M.W.; Lowe, K.L. Isolation of a Naturally-Occurring Nickel Resistance Plasmid from a Rare Hypersaline Estuary (Laguna Madre, Texas, USA) for Potential Use as a Bio-Indicator of Metal Contamination. World J. Microbiol. Biotechnol. 2011, 27, 2163-2171. [CrossRef]

37. Berry, C. The Bacterium, Lysinibacillus sphaericus, as an Insect Pathogen. J. Invertebr. Pathol. 2012, 109, 1-10. [CrossRef] [PubMed]

38. Gould, G.W.; Russell, A.D.; Stewart-Tull, D.E.S. (Eds.) Fundamental and Applied Aspects of Bacterial Spores; Blackwell Science: Philadelphia, PA, USA, 1994.

39. Yap, H.-H. Field Trials of Bacillus sphaericus for Mosquito Control. In Bacterial Control of Mosquitoes and Black Flies; Springer: Dordrecht, The Netherlands, 1990; pp. 307-320.

40. Rojas-Pinzón, P.A.; Dussán, J. Efficacy of the Vegetative Cells of Lysinibacillus sphaericus for Biological Control of InsecticideResistant Aedes aegypti. Parasit. Vectors 2017, 10, 231. [CrossRef] [PubMed]

41. Peña-Montenegro, T.; Lozano, L.; Dussán, J. Genome Sequence and Description of the Mosquitocidal and Heavy Metal Tolerant Strain Lysinibacillus sphaericus CBAM5. Stand. Genom. Sci. 2015, 10, 2.

42. Lozano, L.C.; Ayala, J.A.; Dussán, J. Lysinibacillus sphaericus S-Layer Protein Toxicity against Culex quinquefasciatus. Biotechnol. Lett. 2011, 33, 2037-2041. [CrossRef] [PubMed]

43. Nielsen-Leroux, C.; Charles, J.-F. Binding of Bacillus sphaericus Binary Toxin to a Specific Receptor on Midgut Brush-Border Membranes from Mosquito Larvae. Eur. J. Biochem. 1992, 210, 585-590. [CrossRef] [PubMed]

44. Ferreira, L.M.; Romão, T.P.; Pompílio de-Melo-Neto, O.; Silva-Filha, M.H.N.L. The Orthologue to the Cpm1/Cqm1 Receptor in Aedes aegypti Is Expressed as a Midgut GPI-Anchored $\alpha$-Glucosidase, Which Does Not Bind to the Insecticidal Binary Toxin. Insect Biochem. Mol. Biol. 2010, 40, 604-610. [CrossRef]

45. Dániel-Gómez, M.; Dussán, J. Assessment of the Synergic Effect between Lysinibacillus sphaericus S-Layer Protein and Glyphosate in the Lethality of the Invasive Arboviral Vector Aedes albopictus. Insects 2020, 11, 793. [CrossRef]

46. Penña, G.; Miranda-Rios, J.; de la Riva, G.; Pardo-Loópez, L.; Soberoón, M.; Bravo, A. A Bacillus thuringiensis S-Layer Protein Involved in Toxicity against Epilachna varivestis (Coleoptera: Coccinellidae). Appl. Environ. Microbiol. 2006, 72, 353-360. [CrossRef]

47. Allievi, M.C.; Palomino, M.M.; Prado Acosta, M.; Lanati, L.; Ruzal, S.M.; Sánchez-Rivas, C. Contribution of S-Layer Proteins to the Mosquitocidal Activity of Lysinibacillus sphaericus. PLoS ONE 2014, 9, e111114. [CrossRef] [PubMed]

48. Thanabalu, T.; Porter, A.G. Efficient expression of a 100-kilodalton mosquitocidal toxin in protease-deficient recombinant Bacillus sphaericus. Appl. Environ. Microbiol. 1995, 61, 4031-4036. [CrossRef] [PubMed]

49. Garzón, J.D.; Linares, D.R.A.; Ardila, L.C.L.; Moyano, S.D.P.V. Caracterización Fisiológica y Genética de Cepas Nativas de Bacillus sphaericus. Rev. Colomb. Biotecnol. 2002, 4, 89-99.

50. Weiser, J. A Mosquito-Virulent Bacillus sphaericus in Adult Simulium damnosum from Northern Nigeria. Zentralbl. Mikrobiol. 1984, 139, 57-60. [CrossRef]

51. Rojas-Pinzón, P.A.; Silva-Fernández, J.J.; Dussán, J. Laboratory and Simulated-Field Bioassays for Assessing Mixed Cultures of Lysinibacillus sphaericus against Aedes aegypti (Diptera: Culicidae) Larvae Resistant to Temephos. Appl. Entomol. Zool. 2018, 53, 183-191. [CrossRef]

52. Bernal, L.; Dussán, J. Synergistic Effect of Lysinibacillus sphaericus and Glyphosate on Temephos-Resistant Larvae of Aedes aegypti. Parasit. Vectors 2020, 13, 68. [CrossRef]

53. Aldrich, J.; Nelson, F.D. Linear Probability, Logit, and Probit Models; SAGE Publications: Thousand Oaks, CA, USA, 1985.

54. Microsoft Corporation. Microsoft Excel. Available online: https:// office.microsoft.com/excel (accessed on 20 December 2019).

55. R Core Team. R: A Language and Environment for Statistical Computing; R Foundation for Statistical Computing: Vienna, Austria, 2020; ISBN 3-900051-07-0. Available online: http:/ / www.Rproject.org/ (accessed on 10 May 2020).

56. Tchioffo, M.T.; Abate, L.; Boissière, A.; Nsango, S.E.; Gimonneau, G.; Berry, A.; Oswald, E.; Dubois, D.; Morlais, I. An Epidemiologically Successful Escherichia coli Sequence Type Modulates Plasmodium falciparum Infection in the Mosquito Midgut. Infect. Genet. Evol. 2016, 43, 22-30. [CrossRef]

57. Valzania, L.; Martinson, V.G.; Harrison, R.E.; Boyd, B.M.; Coon, K.L.; Brown, M.R.; Strand, M.R. Both Living Bacteria and Eukaryotes in the Mosquito Gut Promote Growth of Larvae. PLoS Negl. Trop. Dis. 2018, 12, e0006638. [CrossRef] [PubMed]

58. Cunze, S.; Kochmann, J.; Koch, L.K.; Klimpel, S. Niche Conservatism of Aedes albopictus and Aedes aegypti-Two Mosquito Species with Different Invasion Histories. Sci. Rep. 2018, 8, 7733. [CrossRef]

59. Braks, M.A.H.; Honório, N.A.; Lounibos, L.P.; Lourenço-De-Oliveira, R.; Juliano, S.A. Interspecific Competition Between Two Invasive Species of Container Mosquitoes, Aedes aegypti and Aedes albopictus (Diptera: Culicidae), in Brazil. Ann. Entomol. Soc. Am. 2004, 97, 130-139. [CrossRef]

60. Kress, A. Research into the Potential to Adapt and Establish of the invasive Asian Tiger Mosquito Aedes (Stegomyia) albopictus (SKUSE). arXiv 2016, arXiv:1611.10318.

61. Bonizzoni, M.; Gasperi, G.; Chen, X.; James, A.A. The Invasive Mosquito Species Aedes albopictus: Current Knowledge and Future Perspectives. Trends Parasitol. 2013, 29, 460-468. [CrossRef]

62. Ponnusamy, L.; Xu, N.; Stav, G.; Wesson, D.M.; Schal, C.; Apperson, C.S. Diversity of Bacterial Communities in Container Habitats of Mosquitoes. Microb. Ecol. 2008, 56, 593-603. [CrossRef]

63. Echeverry-Cárdenas, E.; López-Castañeda, C.; Carvajal-Castro, J.D.; Aguirre-Obando, O.A. Potential Geographic Distribution of the Tiger Mosquito Aedes albopictus (Skuse, 1894) (Diptera: Culicidae) in Current and Future Conditions for Colombia. bioRxiv 2020. [CrossRef] 
64. Leyton-Ramos, L.M.; Aguirre-Obando, O.A.; Duque, J.E.; García-Merchán, V.H. Wing Metric Variation in Aedes aegypti Effect of Altitude on Wing Metric Variation of Aedes aegypti (Diptera: Culicidae) in a Region of the Colombian Central Andes. PLoS ONE 2020, 15, e0228975. [CrossRef] [PubMed]

65. Bagny Beilhe, L.; Delatte, H.; Juliano, S.A.; Fontenille, D.; Quilici, S. Ecological Interactions In Aedes species on Reunion Island. Med. Vet. Entomol. 2013, 27, 387-397. [CrossRef]

66. Noden, B.H.; O'neal, P.A.; Fader, J.E.; Juliano, S.A. Impact of Inter- and Intra-Specific Competition among Larvae on Larval, Adult, and Life-Table Traits of Aedes aegypti and Aedes albopictus Females: Impact of Larval Competition on Adult Aedes. Ecol. Entomol. 2016, 41, 192-200. [CrossRef]

67. Legros, M.; Lloyd, A.L.; Huang, Y.; Gould, F. Density-Dependent Intraspecific Competition in the Larval Stage Of Aedes aegypti (Diptera: Culicidae): Revisiting the Current Paradigm. J. Med. Entomol. 2009, 46, 409-419. [CrossRef]

68. Alto, B.W.; Lounibos, L.P.; Mores, C.N.; Reiskind, M.H. Larval Competition Alters Susceptibility of Adult Aedes Mosquitoes to Dengue Infection. Proc. Biol. Sci. 2008, 275, 463-471. [CrossRef]

69. McMeniman, C.J.; Lane, R.V.; Cass, B.N.; Fong, A.W.C.; Sidhu, M.; Wang, Y.-F.; O’Neill, S.L. Stable Introduction of a LifeShortening Wolbachia Infection into the Mosquito Aedes aegypti. Science 2009, 323, 141-144. [CrossRef] [PubMed] 